\title{
Academic writing MOOCs - a blended learning approach
}

\author{
Maria Rudneva ${ }^{1 *}$, Nailya Valeeva $^{1}$, Rdouan Faizi ${ }^{2}$ \\ ${ }^{1}$ RUDN University, 6 Miklukho- Maklaya St, Moscow, 117198, Russian Federation \\ ${ }^{2}$ ENSIAS Mohammed V University in Rabat, Morocco
}

\begin{abstract}
The paper discusses a blended learning approach to teaching academic writing using an externally created MOOC fully incorporated into the existing pedagogic design. The authors intend to demonstrate potentials and limitations of mixed model learning in the ESP classroom. To this day there has been little research of repurposing MOOCs for language classes, as they are usually more practical and interactive. However, the authors believe that the online component of the blended course creates an additional dimension for language acquisition and allows to address numerous general issues on academic writing which are not traditionally discussed in ESP/EAP classes. Based on the results of the case study conducted at RUDN university, the study outlines numerous benefits of blended learning trajectory. However, the investigation revealed a few challenges, some of which can be easily remedied, whereas others are of more problematic nature.
\end{abstract}

\section{Introduction}

Since the dawn of MOOC era there have been a few attempts to incorporate online courses in the existing offline academic curriculum. Initially MOOCs were intended as standalone courses designed by instructors to replace their on-site classes [1]. Later developments demonstrated some potential in creating a blended course that would incorporate both online and offline modules that would be seamlessly coupled and completing one another. The socalled blended or hybrid approach to teaching was supposed to facilitate paradigmatic shift from traditional teacher-centric "chalk and talk" model to a more engaging pedagogic setting that would draw on guided discovery as well as independent self-paced learning, hence fostering learners' engagement and overall satisfaction [2], [3]. According to past research [4] "it was the combination of elements in the treatment conditions (which was likely to have included additional learning time and material as well as additional opportunities for collaboration) that produced the observed learning advantages". Early stage blended courses were created as support modules by the on-site instructors, meaning the same person designed both online and offline course components [2], [5], [6]. However, due to complex and expensive nature of MOOC production, the major part of MOOCs nowadays are created by leading HE entities, whereas the remaining academic community is engaged in a challenging

\footnotetext{
*Corresponding author: rudneva-ma@rudn.ru
} 
activity of repurposing and implementing the online courses created by third parties, into existing academic curriculum [7], [8], [9]. These days a few hybrid models have been implemented by various HE entities, each of them aiming at benefitting from the existing MOOCs [7], [9]. Zhan [7] outlines 5 models of hybrid learning based on rationale behind incorporating a MOOC in existing curriculum:

- using components of one or several MOOCs as learning objects (e.g. quizzes, videos, etc) for the existing on-site course;

- $\quad$ flipping the classroom approach, one or several MOOCs are reviewed by learners independently, followed by on-site discussion with the instructor as well as peers;

- replacing the on-site course with MOOC, followed up by in-house formative assessment, based on MOOC content to avoid cheating and plagiarism;

- transferring credits granted for MOOCs once the online courses fit in the curriculum of the HE entity;

- providing various educational services to MOOC participants, i.e. access to libraries, providing space for local learning groups, tuition, conferences and job fairs.

More recent research [10] offers 6 models of coupling on-site and off-site instruction:

- the first, MOOC-based part of the course is fully online, whereas the second part is entirely on-site;

- $\quad$ flipping the classroom: independent MOOC-based learning at home with on-site follow-up discussions and clarifications with peers and instructors;

- canned digital teaching and tutoring: independent off-site MOOC-based learning coupled with personalized tutoring by faculty members during office hours on request;

- $\quad$ canned digital teaching in face-to-face courses: MOOCs are used as recommended textbooks;

- digital interventions: live or remote expert tutoring as a part of residential courses;

- canned digital teaching with remote tutoring: MOOC-based courses with no faceto-face interaction apart from tutor video-conferences.

Despite a number of exciting pedagogic opportunities hybrid courses present certain challenges, especially when it comes to departing from traditional teacher-centric model and focusing on learners' performance. Therefore exploring opportunities and limitations of MOOCs in language classrooms, their role in enhancing L2 productive skills, needs further study.

\section{Methodology}

The paper presents a case study which was set at RUDN university, Moscow. The academic writing course is typically offered every year to $4^{\text {th }}$ year Bachelor's, Master's and $\mathrm{PhD}$ students as a part of ESP curriculum. Due to the demand to increase students' international academic activity, the module was introduced as a part of existing ESP course. Because of limited hours allocated to face-to-face tuition, it was decided to draw on existing educational resources and incorporate a MOOC on academic writing as an off-site module, the expectation was to create another educational dimension, increase learners' exposure to 
academic L2 in self-paced independent environment. A few criteria were offered for selecting a MOOC for the online module:

- correlation between MOOC content and existing curriculum;

- $\quad$ time constraints - the course had to fully take part in the first semester of 2018-2019 academic year;

- brief consistent presentation

The course was offered to 3 groups of students (overall 48 people) enrolled in academic writing programme. The students' language proficiency was B2-C1 according to CEFR and based on previously taken Cambridge certificate tests. The students were requested to register for the course "How to write and publish a scientific paper" by École Polytechnique, which was offered on coursera.org in November-December 2018. The course includes 5 modules. In each module, there is a set of video lectures, and a set of review questions intended to provide the essential knowledge of the scientific communities on how to build a research paper. The course is described as one prepared by $\mathrm{PhD}$ students for $\mathrm{PhD}$ students. The learners were required to enroll and complete the course on Coursera platform - watch videolectures, complete quizzes and written assignments. Participation in discussion forums was optional. Upon completion of the online tasks the students were asked to make screenshots and email them to the instructor, their results contributed to their overall semester scores for ESP. The instructor allocated time during the on-site class for the follow-up discussion of the MOOC modules. The students were required to complete the online course within 8 weeks, which is half as fast as suggested by the designed curriculum. The rationale behind breaking the course in smaller chunks was in more detailed discussion of offered materials. In postSoviet Russia written assignments are not typical for HE entities, for the majority of students writing a research paper is the first experience of independent academic writing.

Table 1 shows the rough layout of the academic writing course. The middle column describes on-site activities, in class the learners were instructed on general academic vocabulary, introduced to Academic Phrasebank guidelines. The right column presents the MOOC curriculum.

Table 1. Academic writing course.

\begin{tabular}{c|l|lr}
\hline \hline Week & \multicolumn{1}{|c|}{ In-class activities } & \multicolumn{2}{c}{ MOOC lecture topics } \\
\hline 1 & $\begin{array}{l}\text { Academic vocabulary: key } \\
\text { nouns, verbs, adjectives and } \\
\text { adverbs. }\end{array}$ & $\begin{array}{l}\text { Why publish a research paper? } \\
\text { Who is your scientific } \\
\text { community? }\end{array}$ \\
\hline 2 & $\begin{array}{l}\text { Academic vocabulary: word } \\
\text { combinations. }\end{array}$ & $\begin{array}{l}\text { How journals work? } \\
\text { Communication with editorial } \\
\text { board. Copyright issues. }\end{array}$ \\
\hline 3 & $\begin{array}{l}\text { Ways of talking about } \\
\text { sources, facts, evidence and } \\
\text { data, numbers and statistics. }\end{array}$ & $\begin{array}{l}\text { Finding good literature. Managing } \\
\text { your references. Tools for storing } \\
\text { references. }\end{array}$ \\
\hline $\begin{array}{l}\text { Ways of talking about graphs } \\
\text { and diagrams, cause and } \\
\text { effect, ideas, reporting what } \\
\text { others say, analysis of results. }\end{array}$ & $\begin{array}{l}\text { Research design: formulating a } \\
\text { research question. Coherence of } \\
\text { research: literature, methodology, } \\
\text { research question and conclusion, } \\
\text { enriching comprehension of } \\
\text { literature. }\end{array}$ \\
\hline \hline
\end{tabular}




\begin{tabular}{c|l|l|}
\hline \hline 5 & $\begin{array}{l}\text { Talking about meaning. } \\
\text { Talking about points of view. } \\
\text { Presenting an argument. }\end{array}$ & $\begin{array}{l}\text { Structure of paper: key } \\
\text { components, do I write in linear } \\
\text { order? }\end{array}$ \\
\hline 6 & $\begin{array}{l}\text { Summarizing and } \\
\text { paraphrasing. }\end{array}$ & $\begin{array}{l}\text { How to write an abstract. } \\
\text { Bibliography styles. }\end{array}$ \\
\hline 7 & $\begin{array}{l}\text { Organizing your writing. } \\
\text { Describing research methods. } \\
\text { Classifying. }\end{array}$ & $\begin{array}{l}\text { After writing: checklist before } \\
\text { submitting a paper. }\end{array}$ \\
\hline 8 & $\begin{array}{l}\text { Evaluation and emphasis. } \\
\text { Summary and conclusion. }\end{array}$ & $\begin{array}{l}\text { Managing reviews, introducing } \\
\text { corrections and re-submitting. }\end{array}$ \\
\hline
\end{tabular}

In a few instances there is misalignment of the on-site activities and online module, therefore additional time was allocated for in-class discussion of independently acquired knowledge. This approach draws on the assumption that on-site instruction includes immediate corrective feedback and peer discussion to enhance academic vocabulary building process. Whereas the online lecture-based component addresses understanding of academic processes from the most generic perspective and does not require specific attention of L2 instructor. Both components of the course had independent homework assignments, however, the on-site part of the course was wrapped around the online curriculum providing linguistic input for the notions that were covered in video-lectures.

\section{Results}

Upon completion of the academic writing module the students were asked to complete a Likert Scale based survey. The students were made aware that the survey was a part of blended learning in ESP research and that their instructor was interested in anonymous evaluation of their perceptions of the course. The students were also asked to provide informal de-identified remarks on their attitude towards blended learning experience. 45 students out of 48 completed the survey, yielding a $93 \%$ response rate. Overall, the students demonstrated enthusiastic attitude towards blended learning experience and appreciated the online component of the course. Among positive aspects they mentioned:

- Clear bottom-up structure of the course;

- $\quad$ Appealing presentation, great idea of a MOOC designed and delivered by students;

- Convenient self-paced learning strategy;

- Valuable information on international publication standards.

The students did not participate in online discussion forums; however, they considered an on-site weekly follow-up a very useful component of the course. The participants considered vocabulary building sessions very useful, they pointed that corrective feedback was essential for better understanding of academic vocabulary, homework assignments were described as challenging yet beneficial, $70 \%$ of the students were very satisfied with the on-site tuition module, $17 \%$ satisfied and $13 \%$ neutral.

Nevertheless, the coupling of the on-site and online course modules presented a few challenges to the learners. The major challenge pointed out by the students was misalignment of the weekly offerings. They mentioned that they would prefer a greater degree of integration of the material covered in video lectures in the on-site materials, a few students arrived to a similar conclusion that although both parts of the course were valuable and informative, they would benefit from better alignment. As novice writers they would prefer 
classroom activities to directly derive from the video lectures and materials covered online. However, supervision of writing a research paper lies outside the domain of ESP classroom and the L2 instructor does not possess necessary expertise to guide through the entire writing process. Having said that, academic English class can not be limited to building academic vocabulary, summarizing and paraphrasing skills, therefore introduction to writing and publishing a research paper must be a valuable component of the academic writing course.

\section{Conclusion}

A MOOC on academic writing can be useful for novice writers, especially in the blended context with the instructor facilitating follow-up sessions. Outsourcing the introduction to global academic community yielded overall positive feedback. However, the participants of the course pointed at coupling challenges, which refer to alignment of online and in-class components of the course. Some of the students were not entirely satisfied with the degree of interdependency of online and offline modules. There are a few reasons for such coupling approach: 1) the skills offered by the MOOC are not covered by the current university curriculum, however, they are the skills graduate students must be efficient in; 2) the followup on-site sessions were designed to specifically address challenges the students came across when completing the MOOC; 3 ) the MOOC was an overload for the instructor and greater cohesion would require even more time and effort on the instructor's side.

\section{Acknowledgements}

This work was supported by the Russian Foundation for Basic Research, grants No. 17-3410303.

This paper was financially supported by the Russian Foundation for Basic Research, grant No. 20-012-22046.

\section{References}

1. P. Hill, Online educational delivery models: A descriptive view. EDUCAUSE Review, 47(6), pp. 84-97. (2012) Retrieved from http://www.educause.edu/ero/article/onlineeducationaldelivery-models-descriptive-view

2. A. Aycock, C. Garnham, R. Kaleta, Lessons learned from the hybrid course project. Teaching with Technology Today, 8(6), (2002). Retrieved from ttp://www.uwsa.edu/ttt/articles/garnham2.htm

3. W. G. Bowen, M. M. Chingos, K. A. Lack, T. I. Nygren, Interactive learning online at public universities: Evidence from randomized trials. New York, NY: Ithaka S+R, (2012). Retrieved from http://www.sr.ithaka.org/sites/all/modules/contrib/pubdlcnt/pubdlcnt.php?file=http://ww w.sr.ithaka.org /sites/default/files/reports/sr-ithaka-interactive-learning-online-at-publicuniversities.pdf\&nid=464

4. B. Means, Y. Toyama, R. Murphy, M. Bakia, K. Jones, Evaluation of evidence-based practices in online learning: A meta-analysis and review of online learning studies. Washington, DC: U.S. Department of Education, Office of Planning, Evaluation, and 


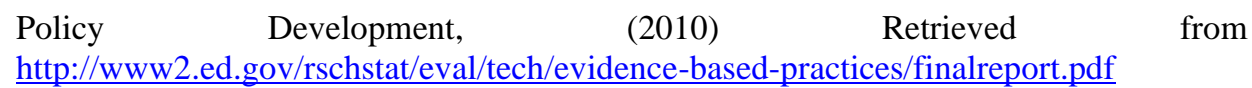

5. J.A. Gilbert, R. Flores-Zambada, Development and implementation of a "blended" teaching course environment. MERLOT Journal of Online Learning and Teaching, 7(2), pp. 244-260, (2011) Retrieved from http://jolt.merlot.org/vol7no2/gilbert 0611.htm

6. M.A. Rodriguez, R. C. R. Anicete, Students' views of a mixed hybrid ecology course. MERLOT Journal of Online Learning and Teaching, 6(4), pp. 791-798, (2011). Retrieved from http://jolt.merlot.org/vol6no4/rodriguez_1210.htm

7. Y. Zhang, Benefiting from MOOC. In World conference on educational multimedia. Hypermedia and Telecommunications, pp. 1372-1377 (2013)

8. C. Sandeen, Integrating MOOCs into traditional higher education: The emerging "MOOC 3.0" era. Change: The Magazine of Higher Learning, 45(6), pp. 34-39, (2013)

9. C. D. Kloos, P. J. Munoz-Merino, M. Munoz-Organero, C. Alario-Hoyos, J.A. PerezSanagustın Ruiperez, J.L. Sanz, Experiences running MOOCs and SPOCs at UC3M. In Proceedings of the IEEE Global Engineering Education Conference (EDUCON), pp. 884-891, (2014)

10. C. D. Kloos, P.J. Munoz-Merino, C. Alario-Hoyos, I.E. Ayres, C. Fernandez-Panadero, C., Mixing and blending MOOC technologies with face-to-face pedagogies. In Proceedings of the IEEE Global Engineering Education Conference (EDUCON), Tallin, Estonia, pp. 967-971 (2015) 